\title{
Photovoltaic Module Energy Rating Methodology Development
}

B. Kroposki, D. Myers, K. Emery, and L. Mrig

National Renewable Energy Laboratory

C. Whitaker and J. Newmiller

Endecon Engineering

Presented at the 25th IEEE Photovoltaic Specialists Conference, May 13-17, 1996, Washington, D.C.

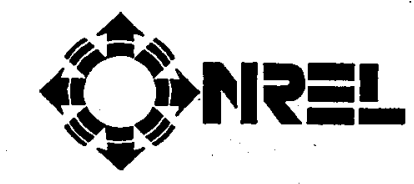

National Renewable Energy Laboratory 1617 Cole Boulevard Golden, Colorado 80401-3393 A national laboratory of the U.S. Department of Energy Managed by Midwest Research Institute for the U.S. Department of Energy under contract No. DE-AC36-83CH10093

Prepared under Task No. PV660103

May 1996 


\section{NOTICE}

This report was prepared as an account of work sponsored by an agency of the United States govemment. Neither the United States govemment nor any agency thereof, nor any of their employees, makes any warranty, express or implied, or assumes any legal liability or responsibility for the accuracy, completeness, or usefulness of any information, apparatus, product, or process disclosed, or represents that its use would not infringe privately owned rights. Reference herein to any specific commercial product, process, or service by trade name, trademark, manufacturer, or otherwise does not necessarily constitute or imply its endorsement, recommendation, or favoring by the United States govemment or any agency thereof. The views and opinions of authors expressed herein do not necessarily state or reflect those of the United States govemment or any agency thereof.

Available to DOE and DOE contractors from:

Office of Scientific and Technical Information (OSTI)

P.O. Box 62

Oak Ridge, TN 37831

Prices available by calling (423) 576-8401

Available to the public from:

National Technical Information Service (NTIS)

U.S. Department of Commerce

5285 Port Royal Road

Springfield, VA 22161

(703) $487-4650$ 


\section{PHOTOVOLTAIC MODULE ENERGY RATING METHODOLOGY DEVELOPMENT}

\author{
B. Kroposki, D. Myers, K. Emery, and L. Mrig \\ National Renewable Energy Laboratory \\ Golden, CO
}

\begin{abstract}
A consensus-based methodology to calculate the energy output of a PV module will be described in this paper. The methodology develops a simple measure of PV module performance that provides for a realistic estimate of how a module will perform in specific applications. The approach makes use of the weather data profiles that describe conditions throughout the United States and emphasizes performance differences between various module types. An industry-representative Technical Review Committee has been assembled to provide feedback and guidance on the strawman and final approach used in developing the methodology.
\end{abstract}

\section{INTRODUCTION}

Based on the results of previous energy ratings research [1], the National Renewable Energy Laboratory (NREL) has initiated an effort to develop a consensus-based approach to rating photovoltaic modules. This new approach was intended to address the limitations of the de facto standard module power rating at Standard Test Conditions $\left(\mathrm{STC}^{1}\right)$... Using technical input from a number of sources and under the guidance of an industrybased Technical Review Committee, the approach described in this paper was developed.

This paper describes testing and computation procedures required to generate a Module Energy Rating (MER) for a particular module type and presents results from some initial validation. The MER consists of 10 estimates of how much energy a single typical module of a particular type will produce in one day, one for each of five different weather/location combinations and two load-types. Because reproduction of these exact testing conditions in the field or laboratory is not feasible, testing was limited and modeling procedures were based on a predefined data set.

The five weather/location combinations provide the basic range of environmental conditions anticipated for typical uses of PV modules in the United States.

Two load types are assumed, corresponding to the two most common loads connected to PV modules: maximum power tracking for grid-tied applications and fixed voltage

1 STC: $1000 \mathrm{~W} / \mathrm{m}^{2}$ irradiance with an Air Mass 1.5 spectrum and $25^{\circ} \mathrm{C}$ cell temperature.

\author{
C. Whitaker and J. Newmiller \\ Endecon Engineering \\ San Ramon, CA
}

for battery charging. For purposes of rating comparison, a 14.4-volt operating voltage per battery is assumed. The $14.4 \mathrm{~V}$ value may be divided by the recommended number of modules and multiplied by the recommended number of batteries to obtain a fixed voltage for purposes of rating. If the manufacturer does not recommend this module for battery application, then the modules need not be rated for fixed voltage. It is assumed that no charge regulation occurs; that is, the module operates at 14.4 volts whenever there is sufficient sun, and that there is no voltage drop between the PV module and battery.

\section{MODULE ENERGY RATING COMPUTATION}

The Module Energy Rating Methodology consists of measuring module characteristics, defining sets of weather and load conditions, and estimating module performance under those conditions using a combination of models. A detailed description of the ratings methodology and module characteristics is given in [2].

Figure 1 shows conceptually the flow of data and the relationships between the various models. The description will start at the right side of the diagram and work our way to the left. First, the algorithms used in each of the computational process (the circles in Figure 1) are described. Next, the input variables (the rectangles in the figure) required for each process are presented.

\section{Model Algorithms}

Energy Model: Energy is computed from the daily power production curves by numerical integration of dc power over time.

DC Power Model: The power output of the module $(P)$ is computed from the plane-of-array irradiance (adjusted for spectral and incidence-angle effects), the module temperature, and appropriate coefficients. Ultimately this methodology will specify only one power model. For validation purposes, five models were investigated: linear interpolation, Anderson [3], Blaesser [4], and the lumped four-parameter (L4P) [5] model. Each model is required to estimate power output for maximum power and fixed-voltage conditions. The linear model depends only on irradiance. The interpolation model uses raw data from a module characterization process. The Anderson and Blaesser models use translation methods. The L4P model is an analytical model that describes a module in terms of an equivalent circuit. 


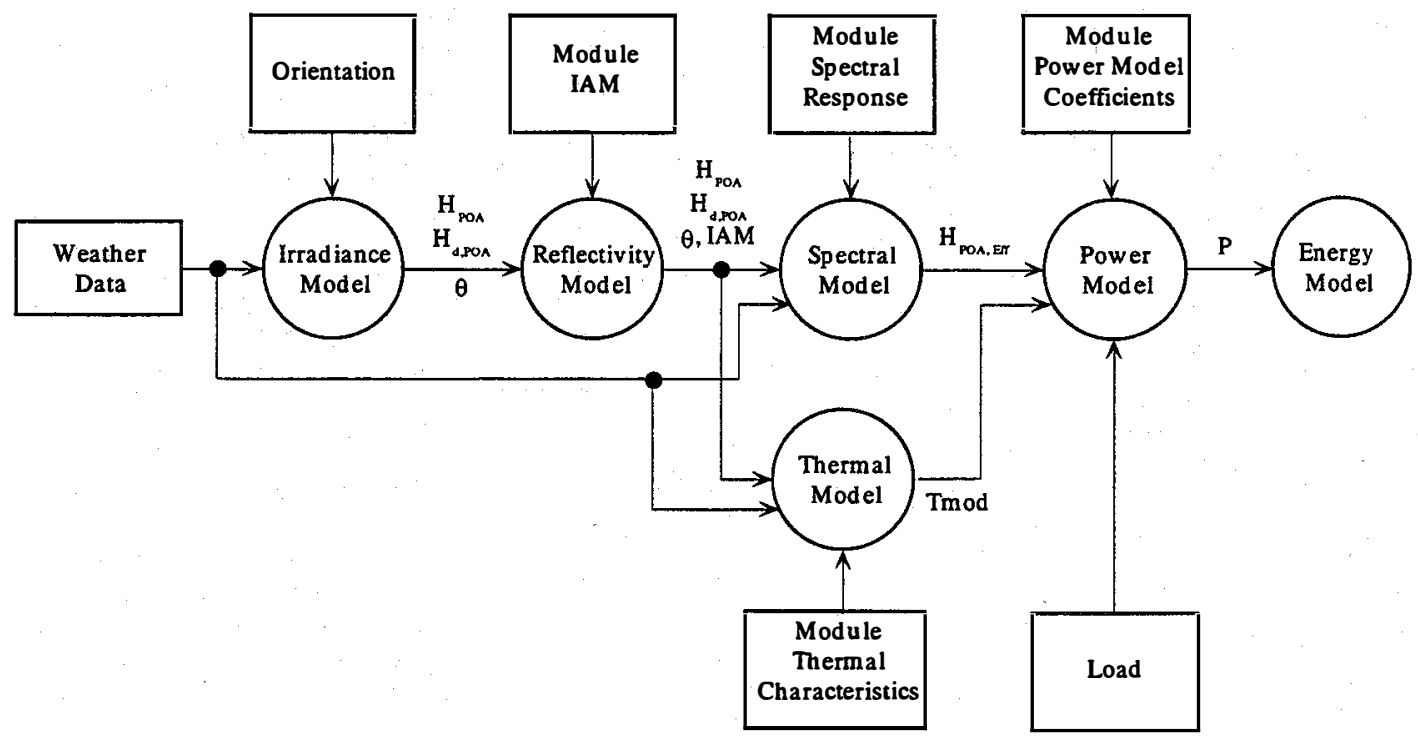

Figure 1. Model flow diagram.

Spectral Model: The spectral model adjusts both the diffuse and beam irradiance incident on the plane-of-array surface as necessary to account for variations in the incident spectrum under the assumed weather conditions. The resulting adjusted irradiances must be referenced to the flash testing spectrum and must account for the module spectral response. The general approach used is to compute the ratio of the actual effective irradiance to the reference effective irradiance, where an effective irradiance is the combined effect of a spectrum and a spectral response. This approach has been discussed Emery [6]. In order to make adjustments based on field and test spectra, these spectra need to be available. Since these data are very rare, a model is used to estimate the spectrum corresponding to the weather data set. To accomplish this, the model uses the perceptible water vapor, solar geometry, diffuse horizontal and plane-of-array (broadband) irradiances, and the beam (broadband) irradiance. In addition, two fixed data sets are required: one representing the exoatmospheric spectrum and clear-sky spectral characteristics, and the other representing a set of empirically derived spectral cloud-cover model coefficients. This model was developed by Nann and Riordan [7].

Module Thermal Model: Another explicit input to several of the PV performance models is module temperature ( $\left.T_{\mathrm{mod}}\right)$. Module output varies by roughly $0.5 \% /{ }^{\circ} \mathrm{C}$ change in temperature. This module temperature coefficient is less for most thin-film devices and for higher-efficiency devices. The temperature of a PV module depends on module construction, module mounting, ambient conditions and conversion efficiency.
Reflectivity Model: The reflectivity model uses the plane-of-array incident irradiance angle $(\theta)$ to obtain an incidence angle modifier (IAM) that accounts for reflection effects. This IAM can be multiplied by the total plane-of-array irradiance ( $H_{P O A)}$ to estimate the total absorbed plane-of-array irradiance for the thermal model, or included in the spectral model normalization computation.

Irradiance Model: The irradiance model transforms commonly available time-correlated global horizontal and direct irradiance and other weather. measurements and plane-of-array orientation into incidence angle and full-spectrum incident beam and diffuse irradiance estimates using astronomical solar-position equations and the Perez diffuse radiation model [8]. The steps in these computations are: determine the true local solar time, compute the local solar position, compute the plane-of-array beam irradiance and incidence angle, and the evaluate the Perez diffuse radiation model.

\section{Model Inputs}

Module Load Type: The power output of any module depends on the voltage or current at which it is operated. Two load types representative of typical installations are specified, maximum power tracking (i.e. grid-connected) and ideal voltage source (fixed voltage).

Location: The location is specified using the latitude, longitude, and time zone.

Environmental Data: The environmental conditions include time, date, global horizontal irradiance, direct normal irradiance, ambient 
temperature, dew point, relative humidity, barometric pressure, wind speed, cloud cover modifiers, and atmospheric absorption coefficients.

Module Characteristics: The module characteristic input parameters include tilt angle, azimuth angle, incident angle modifier coefficients, spectral response function, nominal operating cell temperature (NOCT), efficiency at NOCT, and temperature and irradiance power coefficients.

\section{REFERENCE DAY DEVELOPMENT}

Five reference days were selected from the National Solar Radiation Database as being representative of extreme conditions within the United States. The five reference days were selected based on the criteria listed in Table 1. The table describes four extreme days and one average day, with the set of conditions representing the various types of weather extremes found in the United States.

Table 1. Reference Day Criteria

\begin{tabular}{|l|l|l|l|l|l|}
\hline Profile & $\begin{array}{l}\text { Irrad. } \\
\text { Peak } \\
\text { Watts }\end{array}$ & $\begin{array}{l}\text { Daytime } \\
\text { Temp }{ }^{\circ} \mathrm{C}\end{array}$ & $\begin{array}{l}\text { Wind } \\
\text { Speed }\end{array}$ & $\begin{array}{l}\text { Relative } \\
\text { Humidity }\end{array}$ & $\begin{array}{l}\text { Cloud } \\
\text { Cover }\end{array}$ \\
\hline & & & & & \\
\hline $\begin{array}{l}\text { Sunny- } \\
\text { Hot }\end{array}$ & $>1000$ & $>35$ & Low & Low & $0 \%$ \\
\hline $\begin{array}{l}\text { Sunny- } \\
\text { Cold }\end{array}$ & $>900$ & $<0$ & Avg. & High & $<30 \%$ \\
\hline $\begin{array}{l}\text { Cloudy- } \\
\text { Hot }\end{array}$ & $<400$ & $>30$ & Avg. & High & $>50 \%$ \\
\hline $\begin{array}{l}\text { Cloudy- } \\
\text { Cold }\end{array}$ & $\begin{array}{l}200 \\
400\end{array}$ & $<0$ & High & High & $>90 \%$ \\
\hline $\begin{array}{l}\text { Avg- } \\
\text { Nice }\end{array}$ & $\begin{array}{l}800 \text { to } \\
900\end{array}$ & 20 & Avg. & Avg. & $30 \%$ \\
\hline
\end{tabular}

\section{PRELIMINARY VALIDATION}

This paper presents preliminary results of module energy output for five typical modules representing single-crystal silicon, polycrystalline silicon, amorphous silicon, copper indium diselenide (CIS), and cadmium telluride (CdTe). The paper compares actual energy output measured on various days at NREL with projected energy output from the same modules using the methodology described in this paper. Energy ratings based on five selected reference days will also be compared.

Figure 2 shows the \% from measured energy that each module produced for a maximum-power tracking load as predicted by each of the four tested models and for five different module types. This data is based on a sunny, hot day in July in Colorado. This graph shows that although no single model was ideal in predicting energy, most predictions were within $10 \%$. The linear model did considerably better than the rest in this specific case because it was developed from the same data that it was predicting. This linear model would not have worked as well if it was predicting energy for different types of days.

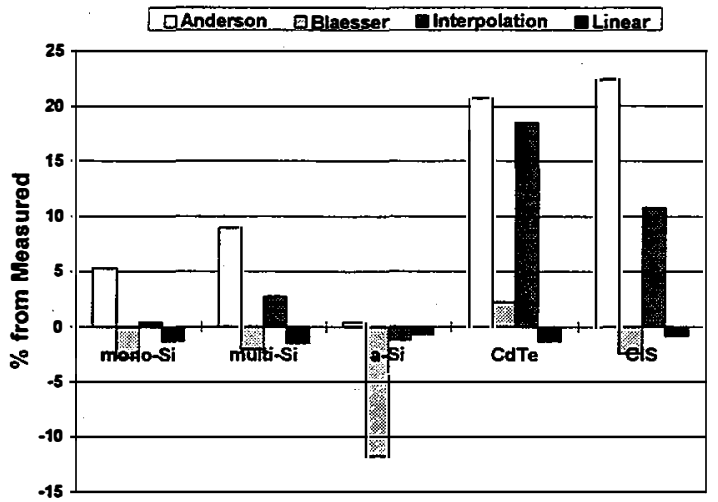

Figure 2. $\%$ from measured value of 4 power models for 5 types of modules using max-power module energy output.

Figure 3 shows the \% from the measured current that each module produced for a fixed-voltage load on a clear sunny day as predicted by each of the three tested for five different types of modules. The linear model was not used because it does not apply to the fixed voltage condition.

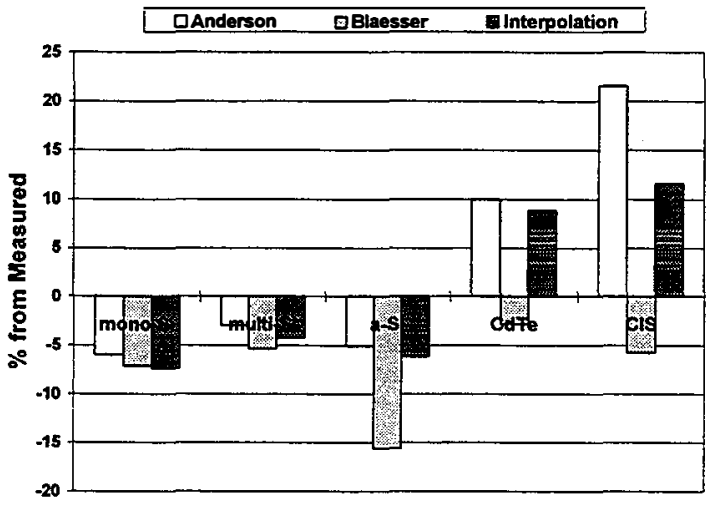

Figure 3 . \% from measured value of 4 power models for 5 types of modules using fixed-voltage current output.

For the most part, the models predicted energy and total current within $10 \%$. There are some modeling problems with modules $\mathrm{CdTe}$ and $\mathrm{CIS}$ because they are research-prototype polycrystalline thin-film modules which were difficult to characterize accurately.

With appropriate models, this approach will provide a set of numbers that an end-user or a system designer can use to compare modules from different manufacturers under conditions that are similar to what the installed array will experience. 


\section{MODULE ENERGY RATING}

Using the procedure outlined in Figure 1, for the reference days defined in Table 1, a module energy rating can be determined. The module energy rating will be a set of 10 numbers based on five different weather conditions and two different load conditions. An example of how this may be displayed on the back of a module is shown in Figure 4. This layout gives fictitious numbers that shows how much energy and current a module produces under the different reference conditions. The peak power energy will be given in watt-hours $(\mathrm{Wh})$, while the fixed voltage current will be described in amp-hours (Ah). This terminology should be useful to the system designer. The MER approach as well as the selected reference days were approved by the TRC.

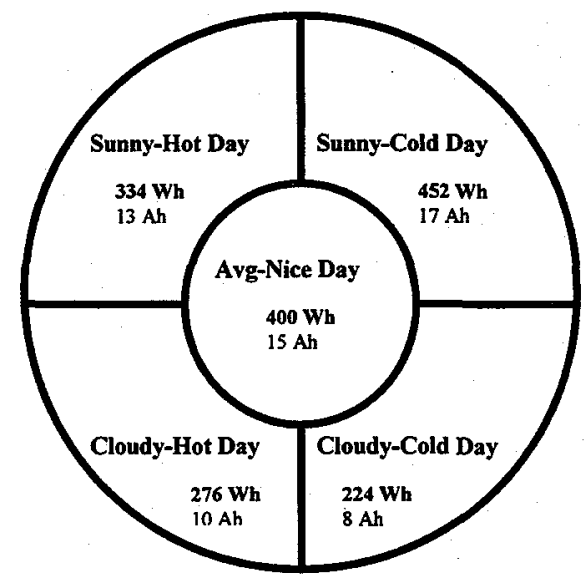

Figure 4. Sample layout for module energy rating [9].

\section{FUTURE WORK}

Continuing work is needed in several areas: model development, input data standardization, and validation of the rating methodology. Work is currently being conducted in all of these areas. Since the power models do not sufficiently address high and low irradiance conditions, power model development is necessary. Input parameters concerning fixed voltages and changing voltages as related to battery charging are still being discussed. A better thermal model needs to be defined. Also standard procedures for developing module performance characteristics (i.e. temperature and irradiance coefficients) are being developed. Selection of the standard extreme and average days is being researched. The validation of this rating methodology will take place once all parameters have been defined.

\section{ACKNOWLEDGMENTS}

The authors would like to thank Jerry Anderson from Sunset Technologies, who developed the idea of using the four extreme and one average reference day for energy comparison. He has also continued to develop new translation equations for module parameters. Thanks to Steve Rummel, Yehoshua Caiyem, and Larry Ottoson for module measurement and characterization. Finally, thanks to Richard DeBlasio and Roland Hulstrom for their continued support of module energy ratings.

\section{REFERENCES}

1. Kroposki, B. et al., "A Comparison of Photovoltaic Module Performance Evaluation Methodologies for Energy Ratings," 24th IEEE, Dec. 1994, pp. 858-862.

2. Kroposki, B. et al., "Development of a Photovoltaic Module Energy Ratings Methodology," 13th NREL PV Program Review, AIP Conference Proceedings 353, May 1995

3. Anderson, A. J., "Photovoltaic Translation Equations: A New Approach," Final Report for Task 1.0 of NREL Subcontract No. TAD-4-14166-01, November 1994.

4. Blaesser G. and W. Zaaiman, "On-Site Power Measurements on Large PV Arrays," 10th E.C. PVSEC, April 1991, pp. 1240-1243.

5. Townsend T., "A Method for Estimating the Long-Term Performance of Direct-Coupled Photovoltaic Systems," MS Thesis, University of Wisconsin, 1989.

6. Emery, K. A. et al. "Methods for Measuring Solar Cell Efficiency Independent of Reference Cell of Light Source," 18th IEEE PVSC, Oct. 1985 pp. 623-628.

7. Nann, S. ,Riordan, C. "Solar Spectral Irradiance under Clear and Cloudy Skies: Measurements and a Semiempirical Model," Joumal of Applied Meteorology, Vol. 30, April 1991, pp.447-462.

8. Perez, R., R. Stewart, R. Seals, and T. Guertin, "The Development and Verification of the Perez Diffuse Radiation Model," Contractor Report SAND88-7030, Sandia National Laboratories, Albuquerque, NM, 1988.

9. Anderson, A. J., "An Energy Rating Concept for Photovoltaic Modules," Final Report for Task 2.0 of NREL Subcontract No. TAD-4-14166-01, March 1995. 